\title{
Effectiveness of Lesson Study Approach on Preservice Science Teachers' Beliefs
}

\author{
Zeha Yakar $^{1} \&$ Duygu Turgut ${ }^{1}$ \\ ${ }^{1}$ Pamukkale University, Faculty of Education, Science Teaching Department, Denizli, Turkey \\ Correspondence: Zeha Yakar, Faculty of Education, Science Education Department, Pamukkale University, \\ 20020 Denizli, Turkey. Tel: 90-258-296-1178. E-mail: zyakar@pau.edu.tr
}

Received: November 7, 2016

Accepted: December 14, $2016 \quad$ Online Published: May 29, 2017

doi:10.5539/ies.v10n6p36

URL: https://doi.org/10.5539/ies.v10n6p36

\begin{abstract}
Beliefs influence teacher decision in the classroom. Because of this reason, understanding teachers' beliefs is important. It is also critical to study teachers' beliefs who integrate science in the classroom. In this study, the effects of microteaching with lesson study approach on preservice science teachers' beliefs about learning and teaching have been analyzed. Teachers' Beliefs Interview (TBI) has been used for determining the development of preservice science teachers' beliefs about learning and teaching. At the end of the study, it was determined that through microteaching with lesson study approach, preservice science teachers' beliefs improved in a positive way that their beliefs significantly changed toward more student-centered. The findings from this study support the notion that application micro teaching with lesson study in Science Teaching Method Course has postitive impact on preservice teachers' beliefs.
\end{abstract}

Keywords: lesson study approach, preservice teachers' beliefs, teacher education program

\section{Introduction}

Teachers' decision making about curriculum and instructional tasks is influenced by many different factors. One of them is beliefs and they play a major role about it (Nespor, 1987; Pajares, 1992). Beliefs are personal constructs and they cannot change easily. In an educational setting, beliefs can be described as teacher's understanding of the nature of knowledge and understanding of a discipline, such as science (Pajares, 1992). Through communication, action and evaluation, the beliefs held by individual are formed and expressed (Pajares, 1992; Tobin, Tippins \& Gallard, 1994). And in general these beliefs influence their action. People behave in a way they believe (Elbaz, 1983; Korthagen \& Kessels, 1999; Northfield, 1998; Pajares, 1992; Shulman, 1986; Tobin et al., 1994). Because of this reason, the study of teacher beliefs has received much attention in recent years (Luft \& Roehrig, 2007; Pajares, 1992; Mansour, 2009; van Uden, Ritzen \& Pieters, 2014; Wong, 2016). These researches focused on the relationship between teachers' beliefs and their teaching. Researchers are beginning to clarify how beliefs are improved and how they affect the teachers' practice. Some researches emphasized that beginning teachers are often significantly influenced through preservice teacher education programs in terms of their beliefs and practice (Kyles \& Olafson, 2008; Joram \& Gabriele, 1998; Stipek, Givvin, Salmon, \& MacGyvers, 2001). In addition, many researches have focused on the importance of methods courses in teacher education programs. The results of these research stated that if enough time and professional support are provided for preservice teachers, the methods courses in teacher education programs affect preservice teachers' conceptual changes in ideology and pedagogy in positive ways regarding to developing beliefs (Brown \& Melear, 2006; Hart, 2002; Stuart \& Thurlow, 2000; Wilson, Floden, \& Ferrini-Munday, 2001).

Nowadays, many research focus on different approach to teacher learning in methods courses such as Lesson Study (Sims \& Walsh, 2009; Parks, 2008; Akerson, Pongsanon, \& Park-Rogers, 2015). Lesson study, which is a form of teacher Professional development that originated in Japan, is closely tied to the idea of learning from teaching (Stigler \& Hiebert, 1999). Through this professional development practice, teachers have an oppurtunity to systematically examine their teaching, with the goal of becoming more effective. Lesson study process typically includes: defining and researching a problem of practice; planning, teaching, and observing the lesson; evaluating the lesson; revising the lesson; teaching and observing the revised lesson; evaluating and reflecting again, and sharing the results (Lewis, Perry, \& Murata, 2006). Through lesson study, teachers can explore real instructional challenges that are faced in their classrooms with their students and they have a chance 
to share best practices and strategies, and to create of relationships and collaborate with peers. Lesson study is also mentioned as an example of pedagogy for preparing teachers for teaching as a lifelong learning process (Hammerness \& Darling-Hammond, 2005). Nowadays several research studies report on successful use of lesson study with preservice teachers (Burroughs \& Luebeck, 2010; Tsui \& Law, 2007; Zhou, Xu, \& Martinovic, 2017).

Application microteaching with lesson study in science teacher education program is very new approach in Turkey. Thus, the present research focuses on the effectiveness of microteaching with lesson study in science teaching method course in terms of changes of preservice science teachers' beliefs about teaching and learning. In this sense, it is thought that the results acquired from this research will contribute to science education and that these results will shed light upon practices in method courses taking place in teacher training.

\section{Method}

\subsection{Application Lesson Study to Methods Courses}

This research-study focused on science teaching methods course in science education which is a four credit/hours required course. The preservicescience teachers attend this course in their fourth year at fall semester. During this course, lesson study approach was integrated to students microteaching. Micro teaching with lesson study approach is an innovation in Methods Courses. The lesson study is a cycle where the group of preservice science teachers/teachers repeatedly goes through the phases, discussion, goal-setting and planning, research lesson.

In this research, integration of lesson study in micro teaching was started with lesson study groups. Students were divided into the groups and each groups consisting of three members. First, each groups chose one science unit from elementary school science curriculum. The members in every groups discussed to determine instructional goals and build lesson plans together according to their science unit. Each group provided the objectives of teaching and plans student-centered strategies to achieve each objective. First week of the application, one member of every each group taught based on the selected learning objectives. After the microteaching, the experience was discussed by other group members and other students in the classroom and instructor joined the discussion. On that basis, the lesson plan revised and the lesson taught again for a similar group. The disscussion cycle repeated again. In this way, all members of the groups completed their microteaching in three weeks. Through this application, preservice science teachers have a chance to share ideas, discuss, work together on planning good teaching, develop professional language and collaborative skills.

\subsection{Participants}

Participants are prospective science teachers of a faculty of education at a state university in one of the cities located on the west part of Turkey. Purposive sampling is used to select the participants. In purposive sampling, it is assumed that the people chosen possess the necessary information about the target population (Franklen \& Wallen, 2003). This research was conducted with 58 volunteered prospective science teachers who had already completed the $3^{\text {rd }}$ grade and passed to the $4^{\text {th }}$ grade and enrolled Science Teaching Method Course- II. These prospective science teachers had already completed the almost all science courses including laboratory courses and pedagogy courses except Student Teaching.

\subsection{Instrument}

The data were collected at the first semester of 2014-2015 academic years from the preservice science teachers through Teachers' Beliefs Interview (TBI), which is an open-ended questionnaire with seven questions (Table 1).

Table 1. Questions used for Teacher Beliefs Interview (TBI)

\footnotetext{
Q1. How do you maximize student learning in your classroom? (learning)

Q2. How do you describe your role as teacher? (knowledge)

Q3. How do you know when your students understand? (learning)

Q4. In the public school setting, how do you decide what to teach and what not to teach? (knowledge)

Q5. How do you decide when to move on to a new topic in your class? (knowledge)

Q6. How do your students learn science best? (learning)

Q7. How do you know when learning is occurring in your classroom? (learning)
}

Source: Luft and Roehrig (2007).

TBI was designed to develop an understanding of how the teachers viewed students and teaching by Luft, 
Roehring, Brooks, and Austin (2003). Participants' responses to each individual question were categorized as traditional, instructive, transitional, responsive, or reform-based. The patterns that emerged from the categories were defined (Luft et al., 2003):

Traditional Responses: These responses are defined as traditional or teacher-centred beliefs that these beliefs focus strictly on the efficient transmission of knowledge from the teacher to the student.

Instructive Responses: These responses are still defined as teacher-centred beliefs. These beliefs involved the teacher providing carefully constructed experiences for the students and minimizing student behavior problems.

Transitional Responses: These responses demonstrate an effective response toward students, however, they do not clearly affirm students' role in the classroom as co-constructors of knowledge.

Responsive Responses: These responses show that the teacher values collaboration in the classroom and they have a desire for students to interact with each to solve problem.

Reform-Based Responses: These responses show a commitment to students being co-constructors of knowledge in the classroom. And they clearly defined role for the teacher as a mediator between students' prior knowledge and the knowledge of the discipline.

\subsection{Data Analysis}

Since the research questions in this study are general and reflect the intention of finding out the understanding of prospective science teachers' on the belief of teaching, qualitative approach was used. In this study, TBI was used to collect data from a sample of 58 prospective science teachers at the first week and at the last week of the Science Teaching Method Course, which they enrolled in the seventh semester. In a class time of 60 minutes, participants wrote about the questions of TBI and coded by two researchers using the TBI coding maps (Luft et al., 2003) with an inter-rater reliability of 0.88 . This value indicates a high level of agreement. The coding maps were used to scale the participants' responses to show movement in the direction of either teacher or student-centered beliefs.

The scoring of teaching beliefs for each teacher was quantified to allow for a statistical analysis of teaching beliefs. Each of the five coded-responses was given a numerical value: 1- a traditional response; 2- an instructive response; 3- a transitional response; 4- a responsive response; and 5- a reform-based response. This resulted in an overall beliefs score between 7 and 35 for each preservice science teachers.

\section{Results}

The findings stated that the pre-development TBI revealed a range in prospective teachers' beliefs from primarily teacher focused (instructive; $\mathrm{n}=12,21 \%)$ to transitional $(\mathrm{n}=46,79 \%)$. On the other hand, the post-development TBI revealed a range in prospective teachers' beliefs from primarily transitional $(\mathrm{n}=39,67 \%)$ to learner-focused (responsive; $\mathrm{n}=19,33 \%$ ).

Four questions of TBI, Q1, Q3, Q6 and Q7, are beliefs about learning. The first question (Q1) of the TBI is "How do you maximize student learning?" The pre-development TBI data have stated that most of the prospective science teachers have Instructive beliefs $(n=32,55.2 \%)$, which they stated that teachers monitors student actions or behaviors during instruction and according to them, they decide what they should to do. In addition, 18 of them (31\%) have transitional beliefs. They stated that teachers create a classroom environment that involves the student. However, the post-development TBI data showed that prospective science teachers' beliefs shifted from teacher centred (instructive; $n=6,10.3 \%)$ to transitional $(n=32,55.2 \%)$ and learner centred (responsive; $\mathrm{n}=18,31 \%$ ) beliefs.

Q3 is "How do you know when your students understand?" The pre-development TBI data have stated that most of the prospective science teachers have transitional beliefs $(n=45,72.4 \%)$, which they focused on their students' response that is related to the presented response. In addition, many prospective science teachers have teacher centred beliefs (traditional, $\mathrm{n}=7,12.1 \%$; instructive, $\mathrm{n}=7,12.1 \%$ ). These prospective science teachers stated that if their students receive the information or if their students demonstrate what has been presented, it shows that students understand the topic. After post-development TBI data have stated that prospective science teachers beliefs moved from teacher centred beliefs to transitional $(n=42,72.4 \%)$ and responsive beliefs $(n=11,19 \%)$. Prospective science teachers with responsive beliefs stated that if their students can use the presented knowledge, they know their understanding.

The responses of pre-development TBI to Q6, "How do your students learn science best?" were most often coded as instructive $(n=56,96.6 \%)$. These prospective science teachers stated that their students learn science best by mimicking the teacher. Post-development responses of Q6 showed that even though many prospective 
science teachers still keep instructive beliefs $(n=43,74.1 \%)$, some of prospective science teachers' beliefs shifted to transitional beliefs $(\mathrm{n}=12,20.7 \%)$.

The last question (Q7) is "How do you know when learning is occurring in your classroom?" The pre-development TBI data have stated that most of the prospective science teachers have teacher centred (traditional, $\mathrm{n}=6,10.3 \%$; instructive, $\mathrm{n}=26,44.8 \%)$ and transitional beliefs $(\mathrm{n}=26,44.8 \%)$. Prospective science teachers with traditional beliefs stated that it is better to focus on students' actions and response during the instruction and in this way; teachers can understand when learning is occurring in their classroom. On the other hand, prospective science teachers with transitional beliefs believed that it is possible to understand when learning occurring in their classroom with determining through subjective conclusions about the students. After post-development TBI data have stated that prospective science teachers beliefs moved from teacher centred beliefs to much more transitional beliefs ( $\mathrm{n}=41,70.7 \%$ ) (see Table 2 ).

Table 2. Beliefs about Learning

\begin{tabular}{|c|c|c|c|c|c|}
\hline & \multirow[b]{2}{*}{ Category } & \multicolumn{2}{|c|}{ Pre-test of TBI } & \multicolumn{2}{|c|}{ Post-test of TBI } \\
\hline & & Frekans & Percent & Frekans & Percent \\
\hline \multirow{5}{*}{$\begin{array}{l}\text { Q1. How do you maximize student learning } \\
\text { in your classroom? }\end{array}$} & Traditional & 5 & 8.6 & 1 & 1.7 \\
\hline & Instructive & 32 & 55.2 & 6 & 10.3 \\
\hline & Transitional & 18 & 31.0 & 32 & 55.2 \\
\hline & Responsive & 3 & 5.2 & 18 & 31.0 \\
\hline & Reform-Based & - & - & 1 & 1.7 \\
\hline \multirow{5}{*}{$\begin{array}{l}\text { Q3. How do you know when your students } \\
\text { understand? }\end{array}$} & Traditional & 7 & 12.1 & - & - \\
\hline & Instructive & 7 & 12.1 & 5 & 8.6 \\
\hline & Transitional & 42 & 72.4 & 42 & 72.4 \\
\hline & Responsive & 2 & 3.4 & 11 & 19.0 \\
\hline & Reform-Based & - & - & - & - \\
\hline \multirow{5}{*}{$\begin{array}{l}\text { Q6. How do your students learn science } \\
\text { best? }\end{array}$} & Traditional & 2 & 3.4 & - & - \\
\hline & Instructive & 56 & 96.6 & 43 & 74.1 \\
\hline & Transitional & - & - & 12 & 20.7 \\
\hline & Responsive & - & - & 2 & 3.4 \\
\hline & Reform-Based & - & - & 1 & 1.7 \\
\hline \multirow{5}{*}{$\begin{array}{l}\text { Q7. How do you know when learning is } \\
\text { occurring in your classroom? }\end{array}$} & Traditional & 6 & 10.3 & - & - \\
\hline & Instructive & 26 & 44.8 & 9 & 15.5 \\
\hline & Transitional & 26 & 44.8 & 41 & 70.7 \\
\hline & Responsive & - & - & 8 & 13.8 \\
\hline & Reform-Based & - & - & - & - \\
\hline
\end{tabular}

Three questions of TBI, Q2, Q4 and Q5, are beliefs about knowledge. Q2 of the TBI is "How do you describe your role as teacher?" The pre-development TBI data have stated that most of the prospective science teachers have teacher centered (traditional, $n=10,17.2 \%$; instructive, $n=16,27.6 \%)$ and transitional beliefs $(n=30,51.7 \%)$. Prospective science teachers with traditional beliefs preferred to focus on information and structure of the instruction. In addition, they preferred to focus on providing experiences to their students. On the other hand, prospective science teachers with transitional beliefs preferred to focus on teacher/student relationships or student understandings. After post-development TBI data have stated that prospective science teachers beliefs moved from teacher centered beliefs to transitional beliefs $(n=38,65.5 \%)$ and responsive beliefs $(n=12,20.7 \%)$. Prospective science teachers with responsive beliefs gave priority to focus on collaboration between teacher and student.

Q4 is "In the public school setting, how do you decide what to teach and what not to teach?" The pre-development TBI data have stated that most of the prospective science teachers have teacher centered beliefs (traditional, $\mathrm{n}=5,8.6 \%$; instructive, $\mathrm{n}=34,58.6 \%$ ). In general, these prospective science teachers emphasized that they decide according to curriculum and/or other school factors or just based on teacher direction, while getting decision on what to teach and what to not teach. In addition, many prospective science teachers have transitional beliefs $(n=19,32.8 \%)$. These prospective science teachers prefer to get decision based on student feedback. After post-development TBI data have showed that prospective science teachers beliefs moved from teacher centred beliefs (instructive, $n=19,32.8 \%)$ to transitional $(n=31,53.4 \%)$. 
The responses of pre-development TBI to Q5, "How do you decide when to move on to a new topic in your class?" were most often coded as teacher centered beliefs (traditional, $n=26,44.8 \%$; instructive, $n=4,6.9 \%$ ). These prospective science teachers stated that teachers decide themselves directly to move on to a new topic or they decide to basic student understanding of facts and concepts. Any of prospective science teachers do not have learner centered beliefs. On the contrary, post-development responses of Q5 showed that even though many prospective science teachers still keep teacher centered beliefs (traditional, $\mathrm{n}=7,12.1 \%$; instructive, $\mathrm{n}=10$, $17.2 \%$ ), some of prospective science teachers' beliefs shifted to responsive beliefs ( $\mathrm{n}=26,44.8 \%$ ). While getting decision, these prospective teachers consider student feedback that potentially involves revisiting concepts (see Table 3).

Table 3. Beliefs about knowledge

\begin{tabular}{|c|c|c|c|c|c|}
\hline & \multirow[b]{2}{*}{ Category } & \multicolumn{2}{|c|}{ Pre-test of TBI } & \multicolumn{2}{|c|}{ Post-Test of TBI } \\
\hline & & Frekans & Percent & Frekans & Percent \\
\hline \multirow{5}{*}{$\begin{array}{l}\text { Q2. How do you describe your role as } \\
\text { teacher? }\end{array}$} & Traditional & 10 & 17.2 & - & - \\
\hline & Instructive & 16 & 27.6 & 6 & 10.3 \\
\hline & Transitional & 30 & 51.7 & 38 & 65.5 \\
\hline & Responsive & 2 & 3.4 & 12 & 20.7 \\
\hline & Reform-Based & - & - & 2 & 3.4 \\
\hline \multirow{5}{*}{$\begin{array}{l}\text { Q4. In the public school setting, how do } \\
\text { you decide what to teach and what not to } \\
\text { teach? }\end{array}$} & Traditional & 5 & 8.6 & - & - \\
\hline & Instructive & 34 & 58.6 & 19 & 32.8 \\
\hline & Transitional & 19 & 32.8 & 31 & 53.4 \\
\hline & Responsive & - & - & 6 & 10.3 \\
\hline & Reform-Based & - & - & 2 & 3.4 \\
\hline \multirow{5}{*}{$\begin{array}{l}\text { Q5. How do you decide when to move on } \\
\text { to a new topic in your class? }\end{array}$} & Traditional & 26 & 44.8 & 7 & 12.1 \\
\hline & Instructive & 4 & 6.9 & 10 & 17.2 \\
\hline & Transitional & 19 & 32.8 & 15 & 25.9 \\
\hline & Responsive & 9 & 15.5 & 26 & 44.8 \\
\hline & Reform-Based & - & - & - & - \\
\hline
\end{tabular}

TBI scores are approximately normally distributed from the both phases of the interviews based on visual analysis of Q-Q plots. A pre-development kurtosis value is -0.316 (standard error of 0.618 ) and a skewness value is -0.414 (standard error of 0.314 ); and a post-development kurtosis value is -0.044 (standard error of 0.618 ) and skewness value is -0.082 (standard error of 0.314 ) also support the assumption of a normal distribution. Pre-development TBI scores are in the range of 11-20 and post-development TBI scores are range of 15-26.

The results of two paired-samples t-tests indicated that, for beliefs about learning, there was a statistically significant difference between pre-development scores and post-development scores $(\mathrm{t}$ value $=-8.060, \mathrm{p}$-value $=$ $0.00<0.05)$. For beliefs about knowledge, the results indicated that there also was a statistically significant difference in scores between pre-development scores and post-development scores $(\mathrm{t}$ value $=-11.301, \mathrm{p}$-value $=$ $0.00<0.05$ ) that change toward more student-centered response (Table 4).

Table 4. Paired sample t-tests for beliefs about learning and beliefs about knowledge

\begin{tabular}{|c|c|c|c|c|c|c|c|c|c|}
\hline & & \multicolumn{5}{|c|}{ Paired Differences } & \multirow{3}{*}{$\mathrm{t}$} & \multirow{3}{*}{ df } & \multirow{3}{*}{ Sig. (2-tailed) } \\
\hline & & \multirow{2}{*}{$\begin{array}{c}\text { Mean } \\
\text { Differences }\end{array}$} & \multirow{2}{*}{$\begin{array}{c}\text { Std. } \\
\text { Deviation }\end{array}$} & \multirow{2}{*}{$\begin{array}{l}\text { Std. Error } \\
\text { Mean }\end{array}$} & \multicolumn{2}{|c|}{$\begin{array}{c}95 \% \text { Confidence Interval } \\
\text { of the Difference }\end{array}$} & & & \\
\hline & & & & & Lower & Upper & & & \\
\hline Pair 1 & $\begin{array}{c}\text { Pre and post } \\
\text { development of TBI } \\
\text { (Learning) }\end{array}$ & -.477 & .451 & .059 & -.596 & -.358 & -8.060 & 57 & .000 \\
\hline Pair 2 & $\begin{array}{c}\text { Pre and post } \\
\text { development of TBI } \\
\text { (Knowledge) }\end{array}$ & -.772 & .520 & .068 & -.908 & -.635 & -11.301 & 57 & .000 \\
\hline
\end{tabular}




\section{Discussion and Conclusion}

Many researches stated that teacher education programs play a significat role in the development of teachers' beliefs about teaching and learning (Hancock \& Gallard, 2004; Nuangchalerm \& Prachagool, 2010; Mansour, 2008). In addition, several past studies have focused on design of methods course and their influence on specific beliefs of preservice teachers (Wilkins \& Brand, 2004; Cinici, 2016; Tarmo, 2016; Zhou, Xu, \& Martinovic, 2017).

In this research, the beliefs of preservice science teachers in the science teaching method course over a fall semester, which was designed microteaching with lesson study, was examined. Whole findings from this research suggest that after participating in the science methods course, preservice science teachers' beliefs about teaching and learning science was changed in a positive way and their beliefs influence their future instructional practices. In addition, the results of this research support the importance of the research that instructional methods used in the course are a critical role on changing preservice science teachers' beliefs about teaching and learning (Cinici, 2016; Brown \& Melear, 2006; Wilkins \& Brand, 2004). The results stated that many preservice science teachers showed congruent increases between their scores on TBI. Preservice teachers who entered the science method course with the most traditionally aligned beliefs recorded a shift toward more responsive beliefs In addition, positive gains in scores were also recorded for preservice science teachers who already had student-centered beliefs when they began to science method course.

As a result of this research, improving the preservice science teachers' beliefs through lesson study approach in micro teaching is possible, eventhough changing personal beliefs is not easy. This application gives preservice science teachers an opportunity to discuss in more detail about the right teaching skills, and to identify and evaluate their beliefs, in this way, they can improve their teching beliefs and most probably these beliefs effect on their teaching practice in a positive way. Through microteaching with lesson study approach, preservice science teachers have a chance to make self-criticism of strengths and weaknesses of their teaching and to talk about what was planned and what was delivered in their teaching session. In addition, quality of teaching can improve through the comments from other group members, because they have a chance to see different teaching on same unit. In conclusion, it is possible to say that integration of microteaching with lesson study is possible and useful and effective for improving of preservice science teachers' beliefs.

This study gives insights about the effectiveness of using microteaching with lesson study on improving preservice science teachers beliefs regarding teaching and learning. According to the results of this study, it may be concluded that the application of microteaching with lesson study is really successful and it is possible to apply the lesson study with microteaching in Science Teaching Methods Courses when developing preservice teachers prepared to use reform-based instruction. This study includes important results regarding science teacher education program and we need more study effects of microteaching with lesson study in Methods Courses on preservice teachers' beliefs and practicum.

\section{References}

Akerson, V. L., Pongsanon, K., Park-Rogers, M. A., Carter, L., \& Galindo, E. (2015). Exploring the Use of Lesson Study to Develop Elemantary Preservice Teachers' Pedagogical Content Knowledge for Teaching Nature of Science. International Journal of Science and Mathematics Education, First Online: 29 October 2015. https://doi.org/10.1007/s10763-015-9690-x

Brown, S. L., \& Melear, C. T. (2006). Investigation of Secondary Science Teachers' Beliefs and Practices after Authentic Inquiry- Based Experiences. Journal of Research in Science Teaching, 43(9), 938-962. https://doi.org/10.1002/tea.20110

Burroughs, E. A., \& Luebeck, J. L. (2010). Pre-service Teachers in Mathematics Lesson Study. The Mathematics Enthusiast, 7(2), 391-400.

Cinici, A. (2016). Preservice Teachers' Science Teaching Self-efficacy Beliefs: The Influence of a Collaborative Peer Microteaching Program. Mentoring \& Tutoring: Partnership in Learning, 24(3), 228-249. https://doi.org/10.1080/13611267.2016.1222812

Elbaz, F. (1983). Teacher thinking: A study of practical knowledge. London: Croom Helm.

Fraenkel, J. R., \& Wallen, N. E. (2003). How to Design and Evaluate Research in Education (5th ed.). New York: McGraw-Hill.

Hammerness, K., \& Darling-Hammond, L. (2005). The design of teacher education programs. In L. Darling-Hammond, \& J. Bransford (Eds.), Preparing teachers for a changing world (pp. 390-441). San 
Francisco: Jossey-Bass.

Hancock, E. S., \& Gallard, A. J. (2004). Preservice Science Teachers' Beliefs About Teaching and Learning: The Influence of K-12 Field Experiences. Journal of Science Teacher Education, 15(4), 281-291. https://doi.org/10.1023/B:JSTE.0000048331.17407.f5

Hart, L. C. (2002). Preservice Teachers' Beliefs and Practice After Participating in an Integrated Content/Methods Course. School Science and Mathematics, 102(1), 4-14. https://doi.org/10.1111/j.1949-8594.2002.tb18191.x

Joram, E., \& Gabriele, A. J. (1998). Preservice Teachers' Prior Beliefs: Transforming Obstacles Into Opportunities. Teaching and Teacher Education, 14(2), 175-191.

Korthagen, F. A. J., \& Kessels, J. P. A. M. (1999). Linking theory and practice: Changing the pedagogy of teacher education. Educational Researcher, 28(4), 4-17.

Kyles, C. R., Olafson, L. (2008). Uncovering Preservice Teachers' Beliefs About Diversity Through Reflective Writing. Urban Education, 43(5), 500-518. https://doi.org/10.1177/0042085907304963

Lewis, C., Perry, R., \& Murata, A. (2006). How should research contribute to instructional improvement? The case of lesson study. Educational Researcher, 35(3), 3-14. https://doi.org/10.3102/0013189X035003003

Luft, J. A., Roehrig, G. H., Brooks, T., \& Austin, B. A. (2003). Exploring the Beliefs of Secondary Science Teachers through Interview Maps. Paper presented at the annual-meeting of the National Association for Research in Science Teaching, Philadelphia, PA.

Luft, J., \& Roehrig, G. (2007). Capturing science teachers' epistemological beliefs: The development of a teacher beliefs interview. Electronic Journal of Science Education, 11(2), 58-63.

Mansour, N. (2008). Science Teachers' Beliefs and Practices: Issues, Implications and Research Agenda. International Journal of Environmental \& Science Education, 4(1), 25-48.

Nespor, J. (1987). The role of beliefs in the practice of teaching. Journal of curriculum studies, 19(4), 317-328. https://doi.org/10.1080/0022027870190403

Northfield, J. (1998). Teacher educators and the practice of science teacher education. In B. Fraser, \& K. Tobin (Eds.), International Handbook of Science Education (pp. 695-706). Hingham: Kluwer Academic Publishers.

Nuangchalerm, P., \& Prachagool, V. (2010). Influences of Teacher Preparation Program on Preservice Science Teachers' Beliefs, International Education Studies, 3(1), 87-91.

Pajares, M. F. (1992). Teachers' beliefs and education research: Cleaning up a messy construct. Review of Educational Research, 62, 307-332. https://doi.org/ 10.3102/00346543062003307

Parks, A. N. (2008). Messy Learning: Preservice Teachers' Lesson-Study Conversations about Mathematics and Students. Teaching and Teacher Education, 24, 1200-1216. https://doi.org/10.1016/j.tate.2007.04.003

Shulman, L. S. (1986). Paradigms and research programs in the study of teaching: A contemporary perspective. In M. C. Wittrock (Ed.), Handbook of research on teaching (pp. 3-36). New York: Macmillan.

Sims, L., \& Walsh, D. (2009). Lesson Study with Preservice Teachers: Lessons from Lessons. Teaching and Teacher Education, 25, 724-733. https://doi.org/10.1016/j.tate.2008.10.005

Stigler, J. W., \& Hiebert, J. (1999). The teaching gap; Best ideas from the world's teachers for improving education in the classroom. New York, NY: The Free Press.

Stipek, D. J., Givvin, K. B., Salmon, J. M., \& MacGyvers, V. L. (2001). Teachers' Beliefs and Practices related to Mathematics Instruction. Teaching and Teacher Education, 17(2), 213-226. https://doi.org/10.1016/S0742-051X(00)00052-4

Stuart, C., \& Thurlow, D. (2000). Making It Their Own: Preservice Teachers' Experiences, Beliefs, and Classroom Practices. Journal of Teacher Education, 51(2), 113-121. https://doi.org/10.1177/002248710005100205

Tarmo, A., \& Stuart, B. (2016). Pre-service Science Teachers' Epistemological Beliefs and Teaching Reforms in Tanzania. Cogent Education, 3, 1-20. https://doi.org/10.1080/2331186X.2016.1178457

Tobin, K., Tippins, D. J., \& Gallard, A. J. (1994). Research on instructional strategies for teaching science. In D. L. Gabel (Ed.), Handbook of research on science teaching and learning (pp. 55-64). New York: Macmillan. 
Tsui, A. B. M., \& Law, D. Y. K. (2007). Learning as Boundary Crossing in School-University Partnership. Teaching and Teacher Education, 23(8), 1289-1301.

Van Uden, J. M., Ritzen, H., \& Pieters, J. M. (2014). Engaging students: The role of teacher beliefs and interpersonal teacher behavior in fostering student engagement in vocational education. Teaching and Teacher Education, 37, 21-32. https://doi.org/10.1016/j.tate.2013.08.005

Wilkins, J. L., \& Brand, B. R. (2004). Change in Preservice Teachers' Beliefs: An Evaluation of a Mathematics Methods Course. School Science and Mathematics, 104(5), 226-232.

Wilson, S., Floden, R., \& Ferrini-Mundy, J. (2001). Teacher Preparation Research: Current Knowledge, Gaps, and Recommendations. Center for the Study of Teaching and Policy, University of Washington. Retrieved August 6, 2008, from http://depts.washington.edu/ctpmail/PDFs/TeacherPrep-WFFM-02-2001.pdf

Wong, S. S. (2016). Development of teacher beliefs through online instruction: A one-year study of middle school science and mathematics teachers' beliefs about teaching and learning. Journal of Education in Science, Environment and Health (JESEH), 2(1), 21-32.

Zhou, G., Xu, J., \& Martinovic, D. (2017). Developing Pre-service Teachers' Capacity in Teaching Science with Technology through Microteaching Lesson Study Approach. EURASIA Journal of Mathematics, Science and Technology Education, 13(1), 85-103. https://doi.org/10.12973/eurasia.2017.00605a

\section{Copyrights}

Copyright for this article is retained by the author(s), with first publication rights granted to the journal.

This is an open-access article distributed under the terms and conditions of the Creative Commons Attribution license (http://creativecommons.org/licenses/by/4.0/). 